\title{
Mixed-type autoimmune hemolytic anemia
}

INSERM

\section{Source}

INSERM. (1999). Orphanet: an online rare disease and orphan drug data base. Mixed-type autoimmune hemolytic anemia. ORPHA:90036

Mixed autoimmune hemolytic anemia is a type of autoimmune hemolytic anemia (AIHA; see this term) defined by the presence of both warm and cold autoantibodies, which have a deleterious effect on red blood cells at either body temperature or at lower temperatures. 